\title{
Pengalaman Ibu Bersalin yang Mengalami Rupture Perineum Derajat 3-4 di RSUD Kabupaten Tangerang
}

\author{
Rita Ayu Yolandia \\ Program Studi DIV Kebidanan Sekolah Tinggi Ilmu Kesehatan Indonesia Maju \\ Jln. Harapan Nomor 50, Lenteng Agung - Jakarta Selatan 12610 Telp: (021) 78894045 \\ Email : ritaayuyolandia@yahoo.com
}

\begin{abstract}
Abstrak
Rupture perineum adalah robekan jalan lahir yang terjadi pada persalinan dengan trouma. Robekan jalan lahir biasanya karena episiotomi, robekan spontan perineum trouma forcep atau vakum ekstrasi. Tujuan dari Penelitian ini adalah Untuk mengetahui Pengalaman Ibu Bersalin yang Mengalami Rupture Perineum Derajat 3-4 Di RSUD Kabupaten Tangerang ada tahun 2015. Metode Penelitian : Penelitian ini menggunakan metode kualitatif dengan pengumpulan data menggunakan wawancara secara mendalam dan terbuka, penelitian ini dilakukan pada bulan September - November. Hasil penelitian : didapatkan bahwa dari $10 \mathrm{ibu}$ bersalin yang mengalami rupture perineum derajat 3 berusia 20-31 th 6 diantaranya melahirkan untuk yang pertama kalinya , 7 orang ibu mengalami persalinan dengan alat bantu vakum , dan semua ibu bersalin mengalami kecemasan akan luka jahitan sehingga membuat para ibu mengalami susah buang air besar, dan $80 \%$ ibu post partum masih belum siap melakukan hubungan suami istri setelah 6 minggu pasca melahirkan. Kesimpulan :10 ibu bersalin yang mengalami rupture perineum mengalami kecemasan, yang membuat para ibu susah buang air besar dan belum siap untuk melakukan hubungan suami istri setelah 6 minggu pasca melahirkan, dan merasa senang dan puas atas pelayanan rumah sakit RSUD Kabupaten Tangerang.
\end{abstract}

Kata Kunci : Jalan Lahir, Pengalaman Robekan

\begin{abstract}
Rupture of the perineum was torn birth canal that occurs in labor with trouma. Laceration the birth canal is usually due to an episiotomy, spontaneous perineal laceration traumatic forceps or vacuum extraction. The purpose of the study This is to know Mother Maternity Experiencing rupture perineum Degrees 3-4 In Tangerang District Hospital there in 2015. Research methods: This study uses a qualitative method of data collection using in-depth interviews and open, this study was conducted in September-November. research result : found that of the 10 mothers who experienced a rupture perineum 3 degrees 6 of them aged 20-31 years who gave birth for the first time, 7 mother went into labor with tools vacuum, and all maternal anxiety would stitches that make women experiencing constipation, and $80 \%$ of post partum mothers are still not ready marital relationship after 6 weeks postpartum. Conclusion : 10 mothers who have experienced anxiety ruptured perineum, which make mothers constipation and not ready to perform sexual intercourse after 6 weeks postpartum, and feel happy and satisfied with the hospital services Tangerang District Hospital.
\end{abstract}

Keywords: Perineum, Experience, Rupture 


\section{Pendahuluan}

Rupture perineum adalah robekan yang terjadi pada saat bayi lahir baik secara spontan maupun dengan alat atau tindakan. Robekan jalan lahir biasanya akibat episiotomy, robekan spontan perineum, trauma forceps atau vakum ekstrasi, atau karena versi ekstrasi. Robekan terjadi bisa ringan (lecat, laserasi), luka episiotomi, robekan perineum spontan derajat ringan sampai rupture perinea totalis (spingter ani terputus), robekan pada dinding vagina, forniks uteri, serviks, daerah sekitar klitoris, dan uretra dan bahkan yang terberat rupture uteri. ${ }^{1}$

Ibu adalah orang tua perempuan dari seorang anak yang merupakan sosok yang luar biasa, namun sangat peka terhadap berbagai masalah kesehatan. Kematian ibu bersalin dan ibu hamil sekarang sudah mencapai $25-50 \%$ hal ini merupakan masalah besar pada Negara berkembang, kematian ini terjadi pada wanita usia subur. $^{2}$

Peningkatan kesehatan ibu merupakan salah satu tujuan Millennium Development Goal's (MDG's) sesuai target Nasional menurut MDGs yaitu menurunkan angka kematian ibu sebesar 3/4 dari angka kematian ibu pada tahun 1990 (450 per 100.000) menjadi 102 per 100.000 yang ingin dicapai pada tahun 2015. AKI (Angka Kematian Ibu ) di dunia pada tahun 2010 menurut WHO adalah 287/100.000 kelahiran hidup, dinegara maju 9/100.000 kelahiran hidup dan dinegara berkembang 600/100.000 kelahiran hidup. Indonesia sebagai Negara berkembang mempunyai AKI yang lebih tinggi dibandingkan dengan Negara -negara ASEAN. ${ }^{3}$

Berdasarkan survey Demografi kesehatan Indonesia (SDKI) tahun 2012 AKI di Indonesia 359/100.000 kelahiran hidup. Jumlah ini meningkat dibandingkan data SDKI tahun 2007 yang besarnya 228 kematian, dan masih merupakan yang tertinggi di Asia. Dan angka kematian ibu di DKI menurut profil kesehatan DKI Jakarta tahun 2012 adalah 97 per 100.000 kelahiran hidup dan di Kabupaten Tangerang sendiri pada Tahun 2014, untuk AKI 47 kasus kematian ibu. ${ }^{4}$ Penyebab utama kematian ibu dinegara berkembang adalah faktor obstetric langsung, yaitu perdarahan post partum, infeksi dan eklamsi. Kelainan perdarahan postpartum yang terjadi pada kala ketiga (kala uri) yaitu retensio plasenta, inversion uteri, dan perdarahanrobekan jalan lahir / Ruture Perineum. Bagi perempuan, perineum sangatlah penting, peregangan dan robekan pada perineum selama proses persalinan dapat melemahkan otot-otot dasar panggul pada dinding vagina. ${ }^{5}$

Trauma pada perineum juga menimbulkan rasa tidak nyaman dan nyeri pada saat melakukan hubungan seksual, Hal yang sering menjadi kehawatiran perempuan hamil adalah terjadinya robekan pada daerah perineum saat bersalin, apabila jika ternyata robekan tersebut harus dijahit, kadang robekan atau perobekan (episiotomy) sebenernya perlu dilakukan sebagai usaha untuk memperlebar jalan lahir dan memudahkan jalan keluar. ${ }^{6}$

Masa postpartum merupakan masa ketika terjadi berbagai perubahan pada wanitapasca salin, baik perubahan fisiologis, psikologis, maupun sosiokultura dan spriritual. Perubahan fisik dan emosional yang kompleks memerlukan adaptasi untuk menyesuaikan diri dengan pola hidup setelah proses persalinan dan peran baru wanita menjadi ibu. Bagi perempuan, perineum sangatlah penting, peregangan dan robekan pada perineum selama proses persalinan dapat melemahkan otot-otot dasar panggul pada dinding vagina. Trauma pada perineum juga menimbulkan rasa tidak nyaman dan nyeri pada saat melakukan hubungan seksual, Hal yang sering menjadi kehawatiran perempuan hamil adalah terjadinya robekan pada daerah perineum saat bersalin, apabila jika ternyata robekan tersebut harus dijahit, kadang robekan atau perobekan (episiotomy) sebenernya perlu dilakukan sebagai usaha untuk memperlebar jalan lahir dan memudahkan jalan keluar. $^{7}$

Rupture perineum dialami oleh $85 \%$ wanita yang melahirkan pervaginam .pada golongan umur 25-30 tahun yaitu 24\% sedangkan pada ibu bersalin usia 32-39 tahun sebesar $62 \%$. Rupture perineum adalah robekan yang terjadi pada saat bayi lahir baik secara spontan maupun dengan alat atau tindakan. Robekan jalan lahir biasanya akibat episiotomy, robekan spontan perineum, trouma forceps atau vakum ekstrasi, atau karena versi ekstrasi.Robekan terjadi bisa ringan (lecat, laserasi), luka episiotomi, robekan perineum spontan derajat ringan sampai rupture perinea totalis (spingterani terputus), robekan pada dinding vagina, forniks uteri, serviks, daerah sekitar klitoris, dan uretra dan bahkan yang terberat rupture uteri. ${ }^{8}$ Faktor penyebab terjadinya rupture perineum terdiri dari faktor ibu, faktor persalinan, dan faktor janin. Faktor ibu yaitu : usia, paritas, partus premature, ibu yang tidak mampu berhenti mengejan, partus yang diselesaikan dengan terburu-buru, odema, dan varises vulva. Faktor persalinan yaitu: ekstraksi 
vakum, forcep, dan embriotomi. Faktor janin yaitu: bayi besar, kelainan presentasi, kelahiran bokong, dan distosia bahu. ${ }^{9}$

Robekan perineum sebenarnya bisa dicegah dengan sebuah metode yang sangat sederhana dan bisa dilakukan semua orang, yaitu dengan melakukan pada daerah perineum atau kerampang vagina. $^{10}$

Dalam penelitian di Sydney sastra melaporkan dampak psikologi dari perempuan yang mengalami trauma perineum yang parah yaitu luas dan kompleks berkisar 0,5-10 \%, beberapa wanita mungkin mengalami salah satu atau semua gejala seperti dyspareunia, stress, flatus, dan beresiko fistula vasikovaginal, penelitian ini difokuskan tidak hanya pada morbiditas tetapi juga pada bagaimana mereka diperlakukan selama kelahiran, proses penjahitan dan periode postpartum. Model perawatan, tingkat kasih sayang dan persahabatan. ${ }^{11}$

Setelah melalui masa kehamilan yang panjang dan persalinan yang berat, perjuangan seorang ibu masih belum usai. Terkadang akan muncul masalah yang terkait dengan proses persalinannya, beberapa wanita mungkin mengalami salah satu atau semua gejala seperti dyspareunia, stress, flatus, dan beresiko fistula vasikovaginal.

Kejadian ibu yang mengalami rupture perineum pada periode Januari - Agustus tahun 2015 sebanyak 1081 ibu melahirkan dengan rupture perineum. $40 \%$ mengalami rupture perineum derajat $1-2$, dan $60 \%$ ibu berasalin mengalami rupture perineum derajat 3-4. Berdasarkan data yang diambil dari rekam medik RSUD Tangerang diketahui ada peningkatan angka kejadian rupture perineum, namun belum diketahui penyebab atau faktor yang berhubungan dengan kejadian tersebut, serta akibat yang dirasakan ibu setelah ibu bersalin yang mengalami Rupture Perineum.

Tujuan dari penelitian ini adalah untuk mengetahui pengalaman ibu bersalin yang mengalami rupture perineum derajat 3-4 di RSUD Kabupaten Tangerang yang dilihat dari psikologis ibu setelah melahirkan, aktivitas fisik yang dilakukan, hubungan intim (suami istri), serta pelayanan yang diterima oleh ibu bersalin di RSUD Kabupaten Tangerang.

Berdasarkan fenomena diatas dengan kejadian rupture perineum derajat 3-4 di RSUD Kabupaten Tangerang yang mengakibatkan perubahan psikologis ibu melahirkan setelah mengalami rupture perineum, Oleh karena itu peneliti ingin mengetahui pengalaman ibu bersalin yang mengalami rupture perineum derajat 3-4 Di RSUD Kabupaten Tangerang pada tahun 2015.

\section{Metode}

Menurut Wawan desain penelitian merupakan strategi untuk mendapatkan data yang dibutuhkan untuk keperluan pengujian hipotesis atau untuk menjawab pertanyaan penelitian dan sebagai alatuntuk mengontrol variable yang berpengaruh dalam penelitian.

Desain penelitian yang digunakan dalam penelitian ini adalah Studi Kualitatif, yang dilakukan untuk melihat lebih dalam tentang pendapat dan perasaan informan yang mungkin tidak dapat terungkap pada penellitian kuantitatif.Dalam penelitian ini tidak ada hipotesis, ada perlakuan, tidak ada pembatasan produk akhir.

Penelitian ini dilakukan di RSUD Kabupaten Tangerang. Pemilihan Lokasi ini dikarenakan bahwa di RSUD Kabupaten tangerang merupakan RSUD dengan distribusi tertinggi Ibu yang bersalin yang mengalami rupture perineum derajat 3-4 di daerah tangerang.

Subjek penelitian adalah sasaran pengamatan atau informan pada suatu penelitian.Karakteristik subjek pada penelitian ini adalah orang- orang yang pernah bersalin di RSUD Kabupaten Tangerang.Objek penelitian merupakan hal yang menjadi titik perhatian dari suatu penelitian.Titik perhatian tersebut adalah 10 ibu bersalin yang mengalami Rupture Perineum derajat 3-4 di RSUD Kabupaten Tangerang pada tahun 2015.

Kriteria inklusi adalah kriteria responden yang memenuhi syarat untuk digunakan menjadi responden.Kriteria inklusi dalam penelitian ini adalah Semua ibu yang melahirkan di RSUD Kabupaten Tangerang setelah 40 hari -3 bulan melahirkan dan Ibu yang melahirkan dengan rupture perineum derajat 3-4.

Kriteria ekslusi adalah keadaan yang menyebabkan subjek memenuhi kriteria inklusi namun tidak dapat diikut sertakan dalam penelitian.Kriteria Eksklusi dalam penelitian ini adalah Semua ibu melahirkan yang persalinan di RSUD Kabupaten Tangerang, lebih dari 3 bulan melahirkan Semua ibu yang melahirkan yang tidak mengalami rupture perineum derajat 3-4, Semua ibubersalin yang mengalami rupture perineum derajat 1 dan 2 . 
Instrument penelitian adalah alat atau fasilitas yang digunakan oleh peneliti dalam mengumpulkan data agar pekerjaannya lebih mudah dan hasilnya lebih baik, dalam arti cermat, lengkap dan sistematis sehingga lebih mudah diollah, instrument dalam penelitian ini berupa lembar pertanyaan untuk dilakukan wawancara, dan alat perekam.

Dalam penelitian ini, peneliti menggunakan Teknik pengumpulan data dengan melakukan Wawancara, Wawancara adalah suatu metode yang dipergunakan untuk mengumpulkan data, dimana peneliti mendapatkan keterangan atau informasi secara lisan dari seorang sasaran penelitian (responden), atau bercakap-cakap berhadapan muka dengan orang tersebut (face to face).

Penulis sangat berperan dalam seluruh proses penelitian, mulai dari memilih topik, mendeteksi topik tersebut, mengumpulkan data, hingga analisis, menginterprestasikan dan menyimpulkan hasil penelitian.

Dalam mengumpulkan data-data penulis membutuhkan alat bantu (instrument penelitian). dalam penelitian ini peneliti menggunakan 3 alat bantu yaitu pedoman wawancara, alat rekam dan alat tulis.

Agar validasi tetap terjaga, maka penelitian ini menggunakan kriteria keabsahan dan keajegan.yang diperlukan dalam suatu penelitian pendekatan kualitatif, hal tersebut adalah Keabsahan Konstrk (Construct validaty ) dan Keajegan (Reability).

Penggunaan metode wawancara mendalam ini meliputi beberapa hal, yaitu menanyakan pertanyaan dengan format terbuka, mendengarkan dan merekamnya dan kemudian menindaklanjuti dengan pertanyaan tambahan yang terkait.

Kelebihan menggunakan wawancara terbuka yang dibakukan diantaranya adalah menjadikan analisis data lebih mudah, karena hal itu memungkinkan untuk menempatkan setiap jawaban responden untuk pertanyaan yang sama secara agak cepat. Dan untuk memudahkan dalam mengorganisasikan pertanyaan dan jawaban yang sama.

Analisis data dalam penelitian ini adalah Mengorganisasikan data yaitu Data langsung dari subjek melalui wawancara mendalam (in-dept interview), dimana data tersebut direkam dengan alat perekam dibantu alat tulis lainnya.Kemudian dibuatkan transkipnya dengan mengubah hasil wawancara dari bentuk rekaman menjadi bentuk tertulis secara verbatim.Data yang telah didapat dibaca berulang-ulang agar penulis mengerti benar data atau hasil yang telah didapatkan.

Kemudian Pengelompokan berdasarkan kategori, tema dan pola jawaban yaitu Berdasarkan kerangka teori dan pedoman wawancara, peneliti menyususn sebuah awal analisis sebagai acuan dan pedoman dalam melakukan pengkodean.dengan pedoman ini peneliti membaca lagi transkip wawancara dan melakukan pemilihan data yang relevan dengan pokok pembicaraan.

Menguji asumsi atau permasalahan terhadap data, Mencari Alternatif penjelasan bagi data, dan menulis hasil wawancara.

\section{Hasil dan Pembahasan}

Penelitian ini dilakukan di Rumah Sakit Umum Daerah (RSUD) Kabupaten Tangerang didirikan pada tahun 1928 dengan menempati sebuah ruangan Bui (penjara) yang bekas lahannya sekarang menjadi lokasi Mesjid Agung Al-Ittihad yang beralamat di Jl. Jend. A. Yani No. 9 Kota Tangerang.

Kabupaten Tangerang mempunyai luas wilayah 959,6 $\mathrm{km}^{2}$ dengan batas-batas wilayah : Sebelah Utara berbatasan dengan Laut Jawa, Sebelah Timur berbatasan dengan Kota Tangerang, Kota Tangerang Selatan dan DKI Jakarta, Sebelah Selatan berbatasan dengan Kabupaten Bogor dan Kota Depok, Sebelah Barat berbatasan dengan Kabupaten Serang dan Lebak.

Informan yang di wawancarai dalam penelitian ini berjumlah 10 informan yaitu $10 \mathrm{ibu}$ bersalin yang pernah melahirkan di RSUD Kabupaten Tangerang, yang mana 10 ibu melahirkan ini mengalami robekan perineum derajat 3-4. Hasil wawancara akan digambarkan dalam masing-masing variable, didapatkan berbagai macam pengalaman ibu bersalin yang sangat berbeda beda yaitu seperti:

"Haduuuh, wah mba saya kan itu melahirkan pertama kali yah, ngelahirin itu aja yah sakitnya minta ampun mba, trus mana lg dibilang ada robekan"informanl".

"serem banget mba, saya fikir robeknya seberapa besar yah, tapi saya pas itu udah pasrah aja ,"(Informan 1)

"iya kadang waktu awal gak banyak gerak, mungkin pas udah mau kesini kalo lg mau nyucikan jongkok gitu yah agak gimana gitu." Informaan 8." 
Tabel 1

Karakteristik Informan

\begin{tabular}{ccccccc}
\hline No & Usia & Jenis persalinan & $\begin{array}{c}\text { Jumlah } \\
\text { anak }\end{array}$ & Paritas & $\begin{array}{c}\text { Derajat } \\
\text { robekan }\end{array}$ & Waktu kejadian \\
\hline $\mathbf{1}$ & 31 th & $\begin{array}{c}\text { Normal (ekstraksi } \\
\text { forcep ) }\end{array}$ & 4 & Multipara & 3 & 3 bln yg lalu \\
$\mathbf{2}$ & 26 th & Normal (vakum) & 2 & Multipara & 3 & 3 bulan yg lalu \\
$\mathbf{3}$ & 22 th & Normal (Vakum) & 1 & Primipara & 3 & 4 bulan yang lalu \\
$\mathbf{4}$ & 24 th & Normal (vakum) & 1 & Primipara & 3 & 3 bulan yang lalu \\
$\mathbf{5}$ & 20 th & Normal (forcep) & 1 & Primipara & 3 & 4 bulan yg lalu \\
$\mathbf{6}$ & 31 th & Normal (vakum) & 3 & Multipara & 3 & 3 bulan yg lalu \\
$\mathbf{7}$ & 25 & Normal (vakum) & 1 & Primipara & 3 & 3 bulan yang lalu \\
$\mathbf{8}$ & 23 & Normal (vakum) & 1 & Primipara & 3 & 3 bulan yang lalu \\
$\mathbf{9}$ & 30 th & Normal (Forcep) & 4 & Multipara & 3 & 3 bulan yang lalu \\
$\mathbf{1 0}$ & 22 th & Normal (Vakum) & 1 & Primipara & 3 & 3 bulan yang lalu \\
\hline
\end{tabular}

Sumber : data rekam medic rsud kabupaten tangerang tahun 2015

Adm, Berdasarkan table 6.1 didapatkan bahwa dari 10 informan yang bersalin yang mengalami rupture perineum diketahui bahwa berusia 20- 31 tahun, melakukan persalinan normal, dan dari 10 informan 7 informaan bersalin dengan alat bantu vakum dan 3 infoman dengan alat bantu forcep. Dan rata rata melahirkan anak pertama, semua informan mengalami rupture perineum derajat 3, waktu kejadian terbanyak terjadi 3 bulan yang lalu .

"Haduuuh, wah mba saya kan itu melahirkan pertama kali yah, ngelahirin itu aja yah sakitnya minta ampun mba, trus mana lg dibilang ada robekan"(informan 1).

"Ya kan saya baru pertama melahirkan, katanya sih ada maslah, tapi saya gak tau yah mba gmna, trus katanya harus ada bantuan pake alat mba" (Informan 2).

"Gmna yah mba, ini kan melahirkan anak yg ke 4 yah, walaupun sudah 3 kali melahirkan saya masih aja takut mba.. hehehe.. apa lagi melahirkan anak yg ke 4 ini dibantu dengan alat, kata bidannya sih ada sedikit kendala, jadi harus di robek saya sih yah pasrah aja mba apa pun yg dilakukan dokter, yg penting saya dan bayi saya selamat, dan setelah anak saya lahir dengan selamat, kata bidannya kemaluan saya harus di jahit lumayan banyak.

"Itu mba 1 bulan pertama itu saya masiih dibantu sama ibu saya mba, setelah itu baru saya mulai belajar melakukan sendiri "(informan 3). "iya masih sih mba, tapi yah mungkin gak sekarang yah hehehe..."(informan 10).

\section{Psikologis ibu bersalin yang mengalami Rupture Perienum derajat 3-4.}

Dari hasil wawancara yang telah dilakukan padaa 10 informan ibu bersalin yang mengalami Rupture perineum derajat 3 yang mengalami persalinan dengan alat bantu ektraski vakum yaitu 7 informan dan 3 informan dengan alat bantu forcep, sehingga menimbulkan dampak psikologis bagi ibu yang mengalaminya semua ibu bersalin mengalami kecemasan. Ibu yang baru melahirkan kerap cemas akan kondisi jahitan perineum, ketakutan ibu post partum yang lain untuk bergerak karena nyeri perineum. Dan dari 10 informan 8 ibu bersalin masih ingin memiliki seorang anak lagi, namun tidak dalam jangka waktu dekat, dan 2 nya tidak ingin memiliki anak lagi namun bukan karena trauma untuk melahirkan karena anaknya sudah banyak.

"serem banget mba, saya fikir robeknya seberapa besar yah, tapi saya pas itu udah pasrah aja," (Informan 1)

"Iya mba pas dikasih tau sama susternya itu mba kalo harus dijahi, dan lumayan banyak mba, saya udah gak bisa mikir apa apa lg mba, saya langsung mumet mba, kaget, ya takut, ya udah pasrah aja mba" (informan 2)

"saya cemas mba, karena pertama kali yah, di kasih tau ada robekan gitu mba, dan harus dijahit mba jadi saya takut mba, nyeri nyeri gitu kan yah mba (Informan 3) 
"Iya mba saya kaget banget mba, takut, saya kan gak tau pasti kan yah mba gmna robeknya"(Informan 4)

"Pusing neng takut bayar mahal, kan makin gede makin mahal yak, gmana yak fikirannya keduit "(Informan 5)

"oh iya benar ... kan dikasih tau tuh bayi gak mau keluar keluar, kepalanya sih katanya udah didepan, rambutnya udah nongol gitu, nah kata bidannya mau kita bantu harus dirobek, ya udah kata aku abis udah gak nahan sakitnya"(informan 6)

"yah saya sedikit khawatir, yah namanya jahitan jadi kita gak bisa angkat angkat yg berat berat apa lagi anak saya udah dua yah mba masih kecil kecil jadi rewel yah mba" (informan 7)

"iya waktu itu dikasih tau sih, waktu bayinya lahir, gak kerasa sih, pas mau dijahit susternya bilang bahwa ini robekannya gede jadi harus dijahit, gak tau sampe berapa sih mba, perasaan saya yah cemas juga, takut, apaanya ini juga kan baru pertama kali juga yah "(informan 8)

"yah walaupun saya sudah pernah mengalami ini sebelumnya, tapi tetap saja mba saya takut, cemas juga karena kan sakit yah .."(informan 9).

" haduuh pastinya takut yah mba apalagi inikan pertama kali yah .. "(informan 10).

Setelah ibu mengalami persalinan dengan rupture perineum antar derajat 3-4, masih kah ada keinginan seorang ibu untuk memiliki seorang anak lagi atau apakah ia mengalami trauma untuk tidak hamil lagi, dari hasil wawancara didapatkan:

\section{"Masih adalah mba" (informan 1)}

“ Kalo aku sih mba kapok mba, tapi yah suamiku mba minta 4 mba, hehe ya gmna yah mba, kalo sekarang sih saya masih kb mba, nanti sih yah masih mau mba, ya masa Cuma 2 mba hehe(ketawa kecil)"(informan 2)

"sebenarnya sih mba saya itu pengennya punya anak 5, tapi setelah anak keempat ini syaa pengen udahan aja mba, dulu sih pernah mba sampe robek gitu waktu anak yang pertama tapi gak separah yg ini" (informan 3)

"Masih mba, saya masih ingin punya anak perempuan "(informan 4)
“Waduuh tar dulu deh"(informan 8).

“iya masih mba, tapi tidak dalam waktu dekat

"keinginan saya sih yah masih ada sih yah mba tapi mungkin tidak dekat dekat ini"'(informan 6)

"wah pengen sih tapi untuk sekarang gak dulu deh hihiiii"(informan 7)

"Saya sih maunya udah cukup 4 aja mba.

Suami saya juga setuju."(informan 9).

"Iya masih sih mba, tapi yah mungkin gak sekarang yah hehee..." (informan 10).

Penelitian sebelumnya tentang kecemasan pada ibu post partum normal di semarang, ditemukan hampir 8 ibu yang baru melahirkan mengalami kecemasan. Ibu yang baru melahirkan kerap cemas akankondisi jahitan perineum, ketakutan ibu post partum yang lain bergerak karena nyeri perineum setelah melahirkan sehingga mempengaruhi kemauan untuk melakukan ambulasi dini.

\section{Aktifitas Fisik ibu bersalin yang mengalami Rupture Perineum derajat 3-4.}

Dari hasil wawancara yang dilakukan pada 10 informan $7 \mathrm{ibu}$ masih mengalami kendala dalam melakukan aktivitas fisik setelah melahirkan, akibat adanya luka jahitan, beberapa ibu post partum yang mengalami luka jahitan mengalami susah untuk buang air besar yang menimbulkan kecemasan dan ketakutan akan terbukanya kembali luka jahitan, dan semua ibu post partum yang mengalami gejala ini merasa terganggu dan sangat mempengaruhi aktivitas fisik yang dilakukan sehari hari.

"Anu lo mba, kata suamiku sih mba aku tuh manja, ya gmna yah mba itu pada sakit loh mba, kalo saya nyuci tuh mba, 2 minggu tuh udah bisa mba, lah kalo yg ini tuh yah mba butuh waktu lama loh mba baru bisa ngerjain pekerjaan rumah mba" (informan 1).

"Itu mba 1 bulan pertama itu saya masiih dibantu sama ibu saya mba, setelah itu baru saya mulai belajar melakukan sendiri “(informan 2).

"Lukanya itu mba sering nyeri, kalo lg mau nyuci baju gitu mba "(informan 3). 
"ya kalo kegiatan sehari hari, saya lumayan lama mba untuk mulai nya lebih lama, dulu waktu lahiran anak yg sebelumnya sih 1-2 minggu udah bisa mba. Kegiatan sehari hari sih dibantuin mba sama sodara, ada neneknya "(informan 4).

"Gmana yah saya kan jualan yak, meskipun sakit tetep aja dibuat gerak lama lama biasa sih, udah mulai jualan itu 2 minggu lah mba saya baru bias beraktivitas seperti biasanya mba, lumayan lama juga yah mba, tapi mau gimana lagi yah mba. (informan 5).

"Abis melahirkan sih yah namanya juga luka sih yah neng yah masih agak perih gitu, tapi sekitar seminggu itu udah mendingan, kan kita juga rajinyah datang kebidan yah buat periksa kata bidannya robekannya udah nyatu , dan saya juga ngerasa udah gak sakit lagi, jadi yah aktivitas biasa" (informan 6).

"pasti ada yah mba, soalnya kan namnya juga ada robekan takut kenapa-napa pasti mengurangi aktivitas saya yah mba" (informan 7).

"iya kadang waktu awal awal gak banyak gerak, mungkin pas udah mau kesini kalo lg mau nyuci kan jongkok gitu yah agak gmna yah masih kebayang baying gitu. Padahal ini udah 2 bulan yah mba tetep aja suka ngerasa ngilu tapi padahal gak papa" (informan 8).

"Iya kalau kendala gitu sih yah pasti ada yah mba, apa lg kalau ada bekas jahitan..saya sih 1 bulan pertama masih dibantuin mba sma ibu saya "(informan 9).

"Iyaa mba karena semua pekerjaan rumah saya masih dibantu sama ibu dan suami saya mba" (informan 10 ).

Banyak ibu post partum yang mengalami susah buang air besar. Beberapa faktor baik fisik maupun psikologis dapat menunda kembalinya fungsi normal usus setelah persalinan. Seperti hasil wawancara berikut ini :

"saya sih mba bawaanya takut, tapi yg saya inget sih mba saya tuh sempet nahan bab 3 hari mba, tapi yah Alhamdulillah sih mba gak ada apa apa, dan ini tuh mengganggu banget mba" (Informan 1).

"Itu loh mba saya suka nahan bab mba, saya suka takut gitu mba, takut jebol lg mba, tapi ya alhamdulillah yah mba sekarang mah udah berani "(Informan 2).

"Iya mba saya merasa perih mba waktu mau buang air kecil mba, ya ampun mba rasanya tuh yah perih gitu mba kayak ada yang luka, mungkin memang lecet kali yah mba, saya jadi menduga duga sendiri mba hehehe" (Informan 3).

Dari hasil wawancara yang dilakukan pada 10 informan 7 ibu masih mengalami kendala dalam melakukan aktivitas fisik setelah melahirkan, akibat adanya luka jahitan, beberapa ibu post partum yang mengalami luka jahitan mengalami susah untuk buang air besar yang menimbulkan kecemasan dan ketakutan akan terbukanya kembali luka jahitan, dan semua ibu post partum yang mengalami gejala ini merasa terganggu dan sangat mempengaruhi aktivitas fisik yang dilakukan sehari hari.

\section{Hubungan Intim Ibu bersalin yang mengalami Rupture Perineum derajat 3-4.}

Dari hasil wawancara yang dilakukan pada 10 informan ibu post partum mengenai hubungan intim suami istri, 8 ibu post partum masih belum siap melakukan hubungan suami istri setelah 6 minggu pasca melahirkan dan 2 nya sudah siap untu melakukan hubungan suami istri. Dan dari 8 ibu post partum yang belum siap, tidak ada keluah dari sang suami, mungkin suami khawatir akan menyakiti istrinya, khusunya jika mendapatkan jahitan saat melahirkan. Dan semua ibu post partum mampu menangani rasa ketakutan yang mereka hadapi hingga akhirnya mereka mampu melakukan hubungan suami istri dengan nyaman.

“ Lumayan lama sih mba, kayaknya sampe 2 bulanan mba, soalnya saya masih takut mba "(informan 1).

"Hahahah ( saya jadi malu mba) berapa lama yah mba, kurang lebih 2 bulan lah mba "(informan 2).

"pas yg ini lama banget mba sampe 3 bulan gitu mba abis lahiran, suami saya sempet marah mba, tapi gmna yah mba orang sayan takut yah mba" (informan 3).

"(tertawa kecil) anu mba yaa lebih lama mba , kalo dulu tuh mba waktu yg pertama sih mba 
, kalo suami minta ya saya bisa mba, kalo yg abis ini saya rada takut mba, masih blm bernai mba "(informan 4).

"Hehehhe... kalo boleh jujur sih mba baru kmren sih, kalo diawal satu bulan 2 bulan sih gak, yah kan masih takut yah ... nah kalo sekarang kan udah 2 bulan lebih yah mba .."(informan 5).

"Saya melakukan hubungan itu 3 bulanan kayaknya mba "(informan 6).

"ahaa jadi malu, kalo abis melahirkan saya off dulu hehe, sebenrnya sih kalo ini masih agak males yah, Cuma kan kita jadi istri harus melayani yah, tapi kalountuk waktunya yah sekitar 2 bulannan lah mba mulai mau "(informan 7).

"Lupa neng pasnya mah, berapa yaah pas darah udah berhenti sih udah coklat coklat gitu "(informan 8).

"Haduuh jadi malu..hihi ..kapan yah mba .. lumayan lama sih mba setelah melahirkan itu ,saya sih mba yang belum siap mba .. untungnya yah suami saya ngerti mba"(informan 9).

"Lumayan lama sih mba, soalnya saya masih ngerasa takut mba, 3 bulanan lah mba kayaknya .."(informan 10).

Hasil penelitian ini sesuai dengan teori yang mengatakan bahwa Setelah 6 minggu pasca melahirkan banyak wanita belum siap untuk melakukan hubungan seksual.

Sebuah penelitian di Australia mendapatkan bahwa enam minggu adalah waktu rata-rata bagi para perempuan pasca persalinan untuk mulai melakukan hubungan seks.Tetapi penelitian tersebut juga menemukan bahwa sekitar setengah dari mereka yang memiliki masalah sejak awal, terus mengalaminya selama tahun pertama pasca persalinan. Penelitian lain menemukan, 20 persen perempuan yang baru pertama kali melahirkan membutuhkan waktu 6 bulan untuk merasa nyaman secara fisik saatbersenggama, dengan waktu rata-rata sekitar 3 bulan.

\section{Pelayanan Rumah Sakit}

Dari hasil wawancara yang dilakukan terhadap 10 infroman yang bersalin di RSUD Kabupaten tanggerang tentang pelayan Rumah sakit, seperti saran dan informasi yang diberikan tentang perawatan luka robekan perineum sehingga dapat menjadi bekal bagi pasien sebelum meninggalkan rumah sakit diadapatkan bahwa semuanya menadapat saran dan informasi tentang perawatan luka robekan perineum dan merasa senang atas pelayanan yang diberikan oleh petugas rumah sakit.

"kalo saran sih, banyak sih mba, yg paling saya inget sih mba, karena saya ada jahitan juga kan yah itu disuruh jaga kebersihan gitu mba, trus disuruh hati hati mba, sama disuruh sering ganti celana dalem. Penghilang rasa sakit?kapan tuh mba? tapi sebelum dijahit itu sempet dikasih tau sih mba kalo mau disuntik gitu." (informan 1).

"Banyak sih mba saran nya mba. kayak disuruh makan yg bergizi gitu mba, trus nanti hati hati dijalan gitu mba "(Informan 2).

"ada sih mba, kata bidannya disuruh jaga kebersihan mba" (informan 3).

"Iya mba, kaya ibu disuruh sering ganti celana dalam, trus jaga kebersihan gitu mba, disuruh sering ganti softek "(informan 4).

"banyak yah mba kayak hubungan suami istri, trus kalo cebok jangan pake air hangat. "(informan 5).

"Ada sih mba, kaya gak boleh angkat yo berat berat, gak boleh terlalu banyak fikirar 7 terus pola makannya juga mba ..(informan 6).

“ iya banyak, dari bidannya sih dari jaga kebersihan, seperti yg buang air kecil sama besar walaupun agak takut harus dibersihin, nanti infeksi, trus mulai dari peminuman vitaminnya, trus buat adeknya, yg tali pusatnya, diaksih tau semua sampe yg darah darahnya, nanti kalo tambah banyak disuruh balik lagi, sama nanti disuruh kunjungan ulang lagi, udah gitu aja sih..(informan 7). “ apaan yak, suruh itu nyusui pake asi aja jangan pake bubuk, kalo soal jahitan sih suruh sering bersihin jangan takut takut ....(informan 8).

"saran yaah ... ada sih mba tapi saya lupa mba hehe .. soalnya kan udah lama yah"(informan 9)

“iyaa kayak suruh menyusui bayinya, makan yg bergizi, trus jaga kebersihan diri juga, trus istirahat yg cukup.. masih banyak sih mba"(informan 10). 
Pelayanan kesehatan yang termasuk dalam kelompok kesehatan masyarakat (public health service) ditandai dengan cara pengorganisasian yang umumnya secara bersama-sama dalam suatu organisasi. Tujuan utamanya untuk memelihara dan meningkatkan kesehatan serta mencegah penyakit, serta sasarannya untuk kelompok dan masyarakat, dan sikap petugas rumah sakit pun sangat mempengaruhi kepuaasan atas pelayan yang diberikan oleh pihak rumah sakit, dalam penelitian ini penulis ingin mengetahui bagaimana kah sikap petugas rumah sakit dalam memberikan pelayan terhadap pasiennya.

\section{Kesimpulan}

Berdasarkan dari hasil wawancara yang dilakukan kepada 10 informan yaitu ibu bersalin yang mengalami Rupture perineum derajat 3 berusia 20-31 tahun, 6 diantaranya melahirkan untuk yang pertama kalinya dan 7 ibu mengalami persalinan dengan alat bantu ektraski vakum yaitu dan 3 ibu dengan alat bantu forcep. $10 \mathrm{ibu}$ bersalin ini pernah melahirkan di RSUD Kabupaten Tanggerang \pm 3 bulan yang lalu, yang memiliki pengalaman yang berbeda beda sehingga dapat disimpulkan :

Berdasarkan Psikologis ibu bersalin yang mengalami rupture perineum derajat 3-4 diketahui bahwa 10 ibu bersalin mengalami kecemasan. Ibu yang baru melahirkan kerap cemas akan kondisi jahitan perineum, ketakutan ibu post partum yang lain untuk bergerak karena nyeri perineum. Dan dari 10 informan $8 \mathrm{ibu}$ bersalin masih ingin memiliki seorang anak lagi, namun tidak dalam jangka waktu dekat dan 2 nya tidak ingin memiliki anak lagi namun bukan karena trauma untuk melahirkan melainakan anaknya sudah banyak.

Berdasarkan Aktifitas fisik ibu bersalin yang mengalami rupture perineum diketahui bahwa dari 10 informan 7 ibu masih mengalami kendala dalam melakukan aktivitas fisik setelah melahirkan, akibat adanya luka jahitan, beberapa ibu post partum yang mengalami luka jahitan mengalami susah untuk buang air besar yang menimbulkan kecemasan dan ketakutan akan terbukanya kembali luka jahitan, dan semua ibu post partum yang mengalami gejala ini merasa terganggu dan sangat mempengaruhi aktivitas fisik yang dilakukan sehari hari.

Berdasarkan Hubungan intim (Suami istri) yang dilakukan setelah melahirkan dengan kondisi ibu mengalami rupture perineum diketahui bahwa dari 10 informan 8 ibu post partum masih belum siap melakukan hubungan suami istri setelah 6 minggu pasca melahirkan. dan 2 nya sudah siap untuk melakukan hubungan suami istri. Dan dari 8 ibu post partum yang belum siap, tidak ada keluah dari sang suami, mungkin suami khawatir akan menyakiti istrinya, khusunya jika mendapatkan jahitan saat melahirkan. Dan semua ibu post partum mampu menangani rasa ketakutan yang mereka hadapi hingga akhirnya mereka mampu melakukan hubungan suami istri dengan nyaman.

Berdasarkan Pelayan Rumah sakit yang diberikan oleh pihak rumah sakit terhadap 10 infroman yang bersalin di RSUD Kabupaten tanggerang tentang pelayan Rumah sakit.

\section{Saran}

Saran dan informasi yang diberikan tentang perawatan luka robekan perineum sehingga dapat menjadi bekal bagi pasien sebelum meninggalkan rumah sakit didapatkan bahwa semua informan merasa puas, senang dan merasa nyaman atas pelayanan yang di berikan oleh petugas rumah sakit dan semua informan mendapat saran dan informasi tentang perawatan luka robekan perineum.

\section{Daftar Pustaka}

1. Sarwono. Ilmu kebidanan. Jakarta: Yayasan Bina Pustaka; 2010.

2. Sarwono. Ilmu kebidanan. Jakarta: Yayasan Bina Pustaka; 2011.

3. Arikunto S. Prosedure penelitian suatu pendekatan praktis. Jakarta: PT.Rineka Cipta; 2006.

4. Aprillia Y. Gentle brith. Jakarta: Yayasan Bina Pustaka; 2010.

5. Townsend. Asuhan masa nifas. Yogyakarta: Rohima; 2011.

6. Virginia S, Hannah Dahlen. Penelitian Kualitatif, Women's experiences following severe perineal trauma. Sydney; 2014.

7. Ani R. Asuhan persalinan normal bagi bidan. Bandung: Raflika Aditama; 2012

8. Tohirin. Metode penelitian kualitatif dalam pendidikan dan konseling. Jakarta: PT.Raja Grafindo Persada; 2011. 
9. Sugiyono. Metode penelitian kuantitatif kualitatif dan R\&D. Bandung: Alfabeta; 2014.

10. Ambarwati dan Wulandari. Asuhan kebidanan. Yogyakarta: Mitra Cendikia Offset; 2011

11. Departemen RI. Asuhan persalinan normal. Jakarta: JNP-KR; 2010

12. Badan Litbangkes Kementrian Kesehatan.Implementasi MDGs 2015 di Indonesia. Jakarta: mdgs-dev.bps.go.id; 2012. Diakses pada tanggal 15 juni 2015.

13. Baradja.Psikologi perkembangan. Jakarta: Studi Press; 2005.

14. Bobak dkk.Buku Ajaran keperawatan Maternitas. Cetakan 2. Jakarta: EGC; 2004.

15. Dahro A. Psikologi kebidanan, analisis perilaku wanita untuk kesehatan. Jakarta: Salemba Medika; 2012

16. DepkesRI.Profil kesehatan indonesia 2010. Jakarta: Kementrian Kesehatan Republik Indonesia; 2011.

17. Depkes.Riset Kesehatan Dasar tahun 2012. penelitian dan pengembangan kesehatan departemen kesehatan RI. badan litbangkes RI 2012. Diakses pada tanggal 15 Juni 2015 dari http://www.diskes.jabarprov.go.id/

18. Dorland WA.N.Kamus Kedokteran Dorland. Jakarta: EGC;2008

19. Garungan. Psikologi social. Bandung: Refika Aditama; 2011. 